This is the pre-peer reviewed version of the following article: Ketchum, A.D. (2020), "All Are Welcome Here"?: Navigating Race, Class, Gender, Sexual Orientation, Age, and Disability in American Feminist Coffeehouses of the 1970s and 1980s. Gender Work Organ. which has been published in final form at https://doi.org/10.1111/gwao.12595. This article may be used for noncommercial purposes in accordance with Wiley Terms and Conditions for Use of Self-Archived Versions

\title{
"All Are Welcome Here"?: Navigating Race, Class, Gender, Sexual Orientation, Age, and Disability in American Feminist Coffeehouses of the 1970s and 1980s Alex Ketchum, PhD
}

This is the accepted, unformatted pre-print: Gender, Work, Organization

Doi for citation: $10.1111 /$ gwao. 12595

In the United States during the 1970s and 1980s, feminists began businesses such as bookstores and restaurants in order to financially support themselves while enacting women's movement politics that challenged sexism. Owning and operating a feminist business in a permanent location required a large capital investment in order to rent space, buy supplies, and pay workers. Women's, and especially lesbians', social positioning due to discriminatory gender, racial, and sexual orientation laws affected whether or not being able to own a restaurant or store was even possible (Murray 2007; Rousseau 2015). Coffeehouses provided an alternative means through which to organize feminist communities around food and drink, with lower initial capital required than restaurants. Feminist coffeehouses in this article will primarily refer to temporary public spaces that served refreshments and whose emphasis was on providing entertainment. Coffeehouses could be one-time benefit shows, such as the benefit for Hera's Journal, hosted by Judy's Café of Philadelphia in 1975. ("Back Cover," 1975) Other coffeehouses, such as Moving Mountain Coffeehouse of the Chicago area, existed from 1974 until 2005, changing venues throughout its history but usually renting out local church basements for Saturday night lesbian feminist music entertainment. Whether in a small town or large city, coffeehouses typically existed in temporary spaces and oftentimes happened in already demarcated feminist and women's spaces like women's centers (which provided legal, health, or other kinds of information and services) or feminist bookstores. In communities where a women's center did not already exist and feminist coffeehouses were the first kind of feminist space in the area, coffeehouses typically took place in church basements, as churches charged little for use of the space, or other low cost spaces. This model of feminist organization expanded opportunities for women of different backgrounds to participate in managing an enterprise in some ways. Without high fixed costs, coffeehouses enabled women with less money, women from marginalized racial groups, and women with marginalized sexual orientations to create women's spaces centered on food, drink, and socializing. However, these spaces were not utopic; racism, ageism, transexclusionism, and classism created tension in their respective communities. As coffeehouse organizers tried to address various inequalities, their approach in treating each identity category as discrete often erased women who experienced multiple forms of oppressions simultaneously.

This article focuses on those who managed and used feminist coffeehouses and is part of a larger body of scholarship that seeks to understand the role of gender in small enterprises (Baines and Wheelock 2000). It takes seriously the role that food and drink played within these power dynamics and was used in order to try to expand access within these feminist organizations. The article begins by exploring the ways in which feminist coffeehouse organizers used food as a tactic to lower barriers to participation. Decisions over how that food was prepared and distributed raised questions about how feminists could work ethically, particularly how women could pay and be paid in a way that aligned with their feminist values. In order to answer those questions, the article examines the organizational structure of feminist coffeehouses, with attention to the demographics of managers, wage scales, and the distribution of labor. Working conditions impacted both feminist coffeehouse organizers and participants because work structures influenced who could be a manager that would, in turn, project her own vision of whom was actually welcomed into the space. The article continues to examine how coffeehouse organizers considered gender, sexuality, age, race, accessibility, and substance use within 
This is the pre-peer reviewed version of the following article: Ketchum, A.D. (2020), "All Are Welcome Here"?: Navigating Race, Class, Gender, Sexual Orientation, Age, and Disability in American Feminist Coffeehouses of the 1970s and 1980s. Gender Work Organ. which has been published in final form at https://doi.org/10.1111/gwao.12595. This article may be used for noncommercial purposes in accordance with Wiley Terms and Conditions for Use of Self-Archived Versions

their communities. It is important to discuss both the management structures and the users of the coffeehouses, as work and socializing was shared, albeit unequally, by all those who participated. Through these examinations, I argue that while American feminist coffeehouses created provisional spaces centered on food, drink, and entertainment that enabled feminist, and primarily lesbian feminist, groups to gather, the question of membership and belonging challenged organizers and users of the spaces to consider what it meant to be a community. Ultimately the choice to treat identity categories as discrete led to lowered attendance, subsequent financial woes, and the demise of the coffeehouses. Although this article focuses on historical case studies within the United States, the findings of this article regarding the political friction around intragroup dynamics elucidate important lessons for feminist organizations today.

\section{$\underline{\text { Feminist Organizational Tension Around Identity and Food }}$}

Coffeehouses are part of a larger history of feminist organizations that struggled to avoid reproducing hierarchies of power across race, class, gender, and sexuality. Researchers across disciplines have documented this phenomenon. Examining the National Women's Music Festival of Bloomington, Indiana, sociologists Donna Eder, Suzanne Staggenborg, and Lori Sudderth importantly asked whether it "is possible to create a community based on shared values and identity that is also open to a diverse constituency" (1995). While those authors acknowledge the difficulty of creating lesbian feminist communities that attend to the needs of marginalized groups, their question extends to other kinds of feminist businesses and organizations. Sociologist Kristen Liddle in More than a Bookstore: The Continuing Relevance of Feminist Bookstores for the Lesbian Community (2005) argues that these spaces were more than places to buy books. Instead, they were central to the formation of lesbian, feminist, and lesbian feminist communities. However, feminist bookstores had to reckon with the meaning of antiracism and feminist accountability in their spaces. Gender studies scholar Kristen Amber Hogan (2016) has looked at the way that feminist bookstores built communities around literature while trying to negotiate issues of race and class. Regarding the divisive role of class within lesbian feminist communities, historian Heather Murray argues that the relationship that lesbian feminists had with money in the 1970s was fraught. She demonstrates that not only did lesbian feminist businesses have to contend with a poorer clientele, but also the idea of making money was seen as exploitative (2007). Gender studies scholar Christina Rousseau, likewise, emphasizes class struggles within lesbian activist organizations as many of the jobs available to women in the 1970s were low waged, precarious, and in feminized job ghettoes (2015). Historian Susan Stryker (2008) and Ann Cvetkovich and Selena Wahng (2001) have documented the exclusion of trans individuals from lesbian feminist businesses and organizations while Emma Heaney writes about the complex history of trans-inclusion in lesbian feminist organizations (2016). In addressing the tensions over who could be included in lesbian feminist communities, women's studies scholar Kathy Rudy personalized her account of the debates around sexuality, gender identity, and race in the lesbian feminist community organizations of Durham, North Carolina (2001). These disparate accounts all point to the complexity of creating and organizing feminist community in North America. This article contributes to this discussion by demonstrating that there was not a simple divide of feminist organizations either addressing or not addressing various oppressions; rather feminist activism was and is a process of working towards equity. Positive intentions toward combating inequity could be misapplied or imperfect. This article speaks to the question raised by Chloé Vitry in a recent issue of Gender, Work, and Organization: "how do we organise collectives that do not reproduce capitalist or neoliberal designs, but where we use our differences to build communities?" (2020). Food and drink influence how these strategies were applied as it was the medium through which individuals connected within feminist coffeehouses. 
This is the pre-peer reviewed version of the following article: Ketchum, A.D. (2020), "All Are Welcome Here"?: Navigating Race, Class, Gender, Sexual Orientation, Age, and Disability in American Feminist Coffeehouses of the 1970s and 1980s. Gender Work Organ. which has been published in final form at https://doi.org/10.1111/gwao.12595. This article may be used for noncommercial purposes in accordance with Wiley Terms and Conditions for Use of Self-Archived Versions

This article focuses on the challenge of building a diverse community through shared labor, food, and drink. As a result, scholarship that emphasizes the role of refreshments and space in structuring groups is influential. Historian Nan Alamilla Boyd (2003) shows how food and drink enable community formation for lesbian, gay, and queer individuals in particular. Sociologist Ray Oldenburg, in The Great Good Place (1989) shows how cafés, coffee shops, and other hangouts form the heart of a community. However, key to the establishment of these places is that they are accessible. Lower barriers to entry, such as low cost food, drink, or tickets makes entrance and participation in the community more possible for a greater number of people. Lower labor inputs and operational costs, such as those at feminist coffeehouses, enabled this kind of heightened accessibility-however feminist coffeehouses were not truly approachable or welcoming to all.

\section{$\underline{\text { Methods }}$}

This article relies on primarily on archival materials, interviews, and entries in lesbian and women's travel guides such as Gaia's Guide. While this article is part of a larger project on feminist restaurants and coffeehouses in which I utilized materials from sixteen archives around the United States and Canada, this article particularly focuses on six case studies: the Iowa City Women's Coffeehouse (19791982); A Woman's Coffeehouse of Minneapolis, Minnesota (1975-1989); the New York Women's Coffeehouse of New York City (1975-1979); the Somerville Women's Coffeehouse of Massachusetts (1978-1989); Las Hermanas in San Diego, California (1974-1980); and the Full Moon Coffeehouse of San Francisco, California (1974-1979/88). Although other examples are mentioned, these case studies from across the United States reflect my findings of the other archives. For this research I utilized the University of Iowa Archives, the University of Minnesota Archives, San Diego LAMBDA Archives, the San Francisco GLBT Archives, the San Francisco Public Library Archives, and the Northeastern University Archives. At these archives there were flyers, meeting minutes, surveys, newsletters, and questionnaires. As this article explains how coffeehouses operated, and in particular who participated, large sections pull from recordings of A Women's Coffeehouse of Minneapolis, Minnesota, which were available as tapes at Jean Nickolaus Tretter Collection in GLBT Studies at the University of Minnesota Archives that I transcribed. The organizers recorded the open community meeting they held, in order to discuss a series of difficulties that the coffeehouse faced. These recording are extremely useful as the meetings showcase the divergent opinions of more than fifteen participants from inside and outside of the organizing collective. The recordings reveal the variety of struggles the coffeehouse faced and shape the thematic organization of this chapter. It is rare to find such a rich resource that includes so many perspectives differing from those of the organizing committee. Since they were recordings on a simple tape recorder, it can be difficult to distinguish between voices. This is why I also include an interview that I conducted with someone who worked at a feminist coffeehouse during this period.

Confusion over terminology arises due to the fact that some cafés called themselves coffeehouses despite being permanent spaces. Also, feminist coffee shops, cafés and restaurants would hold events that they would call "coffeehouse hours" in which musicians, poets, and artists exhibited their work. Coffeehouses existed in large cities such as Philadelphia's Astra Plane Feminist Coffeehouse (1975) and small towns (especially those with universities), such as the Women's Coffeehouse of Ithaca, New York at the Feminist Studio (1979-1982). Coffeehouses' choice of space greatly affected discussions over finances, attendance, and who felt welcome. In this article, I primarily discuss recurring coffeehouses. Lesbians did not run every feminist coffeehouse, but were actively engaged in most of the ones analyzed in this article. To add further confusion, feminist coffeehouses typically were not too original in their titles. Sixteen establishments within my research were entitled "The Women's Coffeehouse." Three were called "Everywoman's Coffeehouse”(sic) and one, “Anywoman”(sic). In order to avoid confusion, I will specify locations of the coffeehouse, even when the location was not part 
This is the pre-peer reviewed version of the following article: Ketchum, A.D. (2020), "All Are Welcome Here"?: Navigating Race, Class, Gender, Sexual Orientation, Age, and Disability in American Feminist Coffeehouses of the 1970s and 1980s. Gender Work Organ. which has been published in final form at https://doi.org/10.1111/gwao.12595. This article may be used for noncommercial purposes in accordance with Wiley Terms and Conditions for Use of Self-Archived Versions

of their formal title such as the Denver, Colorado Women's Coffeehouse (1982) or the Iowa City, Iowa Women's Coffeehouse.

\section{Coffeehouse Aspirations: Coffeehouses Building Community Around Food and Drink}

Coffeehouses were spaces where food and drink enabled socializing. Unlike feminist restaurants that required a large enough population to support the business, feminist coffeehouses could rely on smaller populations purchasing a cup of coffee, snack, or a ticket to attend. Most coffeehouses functioned as nonprofit, dry, social environments. However, even for the coffeehouses that served or allowed alcohol, the emphasis of these spaces was on producing cultural events over profits. As discussed in the collective meeting minutes, when the Iowa City Women's Coffeehouse moved to a larger location and needed to sponsor more activities in order to pay rental fees, the collective decided to host recurring events. Such events included Monday soup dinners for $\$ 1.50$, Thursday breakfasts where patrons paid by donation, and Fridays would have free rest and relaxation sessions in the early evening before concerts, poetry readings, lectures, film screenings, and dances. At the evening events, donations were requested for the coffee and tea provided, but women were welcome to bring their own alcohol (Women's Coffeehouse, n.d.-b). Coffeehouses would sponsor social coffee hours for women to chat and organize entertainment to enjoy. From 1976-1977, Flavia Rando cooked at the New York Women's Coffeehouse. Initially the coffeehouse opened around four in the afternoon every day and served "nothing too exciting- coffee, tea, and snacks - maybe a cheese sandwich" (Rando, 2015). Rando believed that the women attending the coffeehouse deserved good food. Her plan was to cook one wonderful weekly meal that was offered for $\$ 3$. With the exception of the first dinner when her sister helped, Rando, single-handedly, would cook between forty and sixty meals a night on a twenty-four inch stove. As Rando proudly showed in her old journal, her first meal was lasagna, whole wheat bread, and butter. She used real mozzarella and the entire meal cost her $\$ 69.83$ in supplies, which included the cost of transportation to pick up the ingredients and olive oil. The following week she hand-shucked fresh peas and also cooked pasta and spinach ricotta pie. Rando emphasized that she was cooking "family meals." She made about $\$ 1.10$ per hour, but the main reason she wanted to cook the meals was to provide people with special vegetarian food at an affordable price. At feminist coffeehouses, food and drink acted as a vehicle to enable community building.

Feminist coffeehouses aimed to keep food and ticket prices low in order to make events accessible. However, low prices would mean that either the food, the financial security of the coffeehouse operation, or those working who sought to maintain it, would suffer. This dilemma speaks to a dominant dilemma in feminist coffeehouses and feminist organizations more broadly - how could feminists work ethically? How could the space and refreshments be priced in a way that they would be accessible to women with financial constraints? How could women pay and be paid in a way that aligned with their feminist values? If women were not paid to organize the coffeehouse, how would that affect the diversity within the coffeehouse management structures and attendance? While food and drink could create a means through which to gather and build community, it also limited the accessibility for some women to participate and thus challenged coffeehouses' mission statements.

\section{Who ran coffeehouses?}

The typical feminist coffeehouse management arrangement was a collective of women, primarily lesbians, who ran the space as volunteers or for small stipends. These women would organize food, drinks, and entertainment including performances, music, and dancing. A Women's Coffeehouse of Minneapolis paid its collective from 1975-1985. When the collective members were seeking to add a new member, they wrote on the job application, "we are a collective of six lesbians who work together to produce A Woman's Coffeehouse and we are looking for a lesbian to join us. This is not a salaried 
This is the pre-peer reviewed version of the following article: Ketchum, A.D. (2020), "All Are Welcome Here"?: Navigating Race, Class, Gender, Sexual Orientation, Age, and Disability in American Feminist Coffeehouses of the 1970s and 1980s. Gender Work Organ. which has been published in final form at https://doi.org/10.1111/gwao.12595. This article may be used for noncommercial purposes in accordance with Wiley Terms and Conditions for Use of Self-Archived Versions

position, but collective members receive a stipend" (A Woman's Coffeehouse Community, n.d.). At a later community meeting, they explained how much pay each member received: $\$ 10$ a week, except Candace, the main manager, who made $\$ 100$ a month. Relative to the time and energy required to organize the coffeehouse, this pay was low. Across the country, at the Full Moon Coffeehouse of San Francisco, California (1978-1979), the main collective, which called itself the "small collective," received small stipends and the larger collective worked for free (Full Moon Open Community Letter, n.d.). Most coffeehouses did not pay the people who worked there; this influenced the makeup of the management as only women with enough financial flexibility could afford to not be paid.

The fiscal constraints of coffeehouses impacted efforts to diversify leadership. On the job application looking for a lesbian to join the organizing collective of A Woman's Coffeehouse of Minneapolis, the form stated, "We want to open the collective to women of varied cultures, backgrounds and abilities. IF you are interested and can meet the following requirements, we encourage you to apply" (A Woman's Coffeehouse Community, n.d., emphasis in document). Applicants had to: either "live chemically free," eschewing alcohol and recreational drugs, or be supportive of chemically free space; be able to make a one year commitment; be able to work at least one night on most weekends; and be able to attend collective meetings every other Sunday afternoon (A Woman's Coffeehouse Community, n.d.). Although the application stated that they were looking for diversity, the collective still wanted collective members to embody the coffeehouse's mission statement of creating a lesbian chemical free space. Furthermore, even if the collective said that it sought out diversity, the kinds of parameters for the applications meant that only certain kinds of women would be able to devote that kind of time, thus limiting class diversity. Furthermore, as some participants mentioned in an open coffeehouse community meeting, racial diversity would likewise be limited as lesbian women of color in Minneapolis in 1983 as a group were often lower class (A Woman's Coffeehouse Community, 1983). To deal with these issues and in order to mitigate some of the difficulties of running a coffeehouse, organizers sought other work arrangements.

When the managing collectives sought out additional help in organizing the events, responses were mixed. At the Minneapolis' A Women's Coffeehouse open community meeting, the managers asked for the women at the meeting to join a set of committees. There was the survey committee; the committee of handywomen (to make physical improvements, place lights for artwork, and affix ceiling fans); the stereo committee (to buy a second turntable, update sound equipment to play the songs back to back, and to establish expertise on sound equipment); the task force on race issues; a music committee (tasked with buying records and continually assessing how to adapt the music for the majority's preferences); an advisory board for women who wanted to take on some smaller tasks; a mailing committee (to meet once every two months to send out the calendar); and a lights and sound committee (especially for special events). The core collective of managing members intended to retain their positions, but they wanted to delegate tasks. They believed that in addition to personally needing to spread out the work, coffeehouse members who joined committees would then feel more invested in making the space better. As Janice, a participant at the meeting, stated, she liked "the idea of committees. People have joined the collective that have poured their life into it [with a] high level of dedication desired. Committees will allow more diversity-- so more diverse types of people [could] join the collective without giving as much time" (A Woman's Coffeehouse Community, 1983). At that meeting, other participants expressed support towards the idea of committees and also suggested the creation of a greeting committee to deal with the fact that sometimes new women would come to the coffeehouse and feel isolated (A Woman's Coffeehouse Community, 1983). While the committee members would not be paid, the smaller commitment was thought to create opportunities for new women to participate. The collectives that organized coffeehouses faced immense pressures and committees were one way of mitigating that pressure. 
This is the pre-peer reviewed version of the following article: Ketchum, A.D. (2020), "All Are Welcome Here"?: Navigating Race, Class, Gender, Sexual Orientation, Age, and Disability in American Feminist Coffeehouses of the 1970s and 1980s. Gender Work Organ. which has been published in final form at https://doi.org/10.1111/gwao.12595. This article may be used for noncommercial purposes in accordance with Wiley Terms and Conditions for Use of Self-Archived Versions

Coffeehouse collectives typically were comprised of dedicated groups of women who took their duties extremely seriously. Being part of these collectives meant facing criticism, hard work, and little or no pay, but occasional appreciation. On December 12, 1981, the Iowa Women's Coffeehouse collective received a letter that stated,

many of us in the community wanted a C.H. [coffeehouse]. Quite a few of us did things to help make it happen. You all, the collective, hung up in there every week, shouldered most of the burden, will end up taking most of The Flack and will no doubt get little verbal or physical appreciation. This dyke is giving you this little expression of my personal appreciation...You are beautiful!! (Thank You, 1975-1982)

Collectives made coffeehouses possible. These feminist coffeehouses provided a valuable resource to their local communities, becoming centers for socializing, entertainment, resource sharing, and activism. While the official collectives were key for the coffeehouses to function, participants actively contributed to the functioning of the coffeehouse. However, the material conditions of collective members and coffeehouse participants meant that women with more privilege within the lesbian feminist community continued to hold positions of leadership and power and thus were able to exert more influence in the coffeehouses, which then impacted who would want to attend the coffeehouses.

\section{Who were coffeehouses for?}

First and foremost [we want] to provide a safe women-only space. All women, regardless of age, creed, sexual preference, political beliefs, race, etc. are welcome here. Our recognition and acceptance of our diversity and differences allows us as a community to share, learn, grow, and become stronger. We want this space available and accessible to all women, both physically and financially. The Women's Coffeehouse is a space for almost any kind of event (except maybe roller-skating).

In the fall of 1981, the pledge committee of the Women's Coffeehouse of Iowa City released a letter to the regular users of the coffeehouse, restating the goals of the coffeehouse and claiming that all women were welcome there (Women's Coffeehouse, 1981). The actual reality of who was welcomed at coffeehouses and who felt comfortable to eat, drink, and socialize in coffeehouses was different. Building community at coffeehouses was complex. Although food and drink could invite participation, internal power dynamics posed challenges. Coffeehouse collectives constantly questioned and renegotiated tensions surrounding race, sexuality, gender, age, class, and substance use. Discussions over a coffeehouse's goals typically became discussions about the kinds of people coffeehouses aimed to serve. For example, at the Somerville Women's Coffeehouse collective meeting in 1979, the meeting minutes indicate that the members resolved to exclude men. The organizers stated, "we want to reach all women, not just the feminist community" and "provide an atmosphere conducive both to being by yourself as well as sharing a time with friends" (Meeting Minutes, 1979). They sought to act as an information network for the women's community and make the space available for other community groups. Regarding child-care, the collective members discussed the possibility of providing it for mothers and admitted, "We decided that if there is a need for this, the mothers might organize a childcare network among themselves" (Meeting Minutes, 1979). It would be drug and alcohol free, but the collective would attempt to provide for the needs of both smokers and non-smokers and suggested dividing sections of the room. Instead of alcohol, it would serve fresh fruit, juices, healthy snacks, and hot drinks. Space and time would be made available for local performers, artists, and other events. These kinds of lists were not unique to the Somerville Women's Coffeehouse collective. It is notable that in its initial meetings, no notes recorded how the collective would react if transwomen wanted to join the 
This is the pre-peer reviewed version of the following article: Ketchum, A.D. (2020), "All Are Welcome Here"?: Navigating Race, Class, Gender, Sexual Orientation, Age, and Disability in American Feminist Coffeehouses of the 1970s and 1980s. Gender Work Organ. which has been published in final form at https://doi.org/10.1111/gwao.12595. This article may be used for noncommercial purposes in accordance with Wiley Terms and Conditions for Use of Self-Archived Versions

collective, as this question became a point of contention for many feminist coffeehouses. ${ }^{1}$ Mixing discussions of food and entertainment while addressing questions about the gender, age, race, sexual orientation, and able-bodiedness of the desired participants were common at feminist coffeehouses. However, while these discussions tended to understand the relationship of refreshments and entertaining to community building, there was less awareness of how the treatment of various oppressions as discrete factors threatened that community.

The following sections of this article are arranged around identity categories, not to erase the lived experiences of women's intersecting identities, but rather to reflect the manner in which feminist coffeehouses approached various oppressions inside their spaces. Within meeting minutes, event programming, and recorded discussions, the feminist coffeehouses approached issues of race, class, gender, age, accessibility, and sexual orientation as separate categories to be addressed one at a time. In contemporary discourse of intersectional feminism, this approach may appear bizarre, yet it reflected the manner in which the coffeehouse organizers engaged with these conversations. This approach did not fulfill the needs of all coffeehouse attendees and potential attendees and thus could dissuade participation while the coffeehouses aimed to increase diversity. By treating these categories as distinct within this article, these tensions are made more apparent.

\section{Gender and sexuality}

I just want to say that one issue that we have not addressed tonight is that I have a lot of straight women friends that would like to come here but would not feel comfortable here. If we are going to be a lesbian coffeehouse let's call ourselves a lesbian coffeehouse. If we are going to be a women's coffeehouse we need to be receptive to other women who aren't lesbians.

-A Woman's Coffeehouse of Minneapolis: Open Meeting, 1983

At A Woman's Coffeehouse of Minneapolis' open meeting, one participant wanted to know if it was a space for all women or just for lesbians. Questions over what the word "woman" meant was not restricted to this Minnesota coffeehouse. During the 1970s and 1980s, the word "woman" could be code for lesbian, either intentionally or unintentionally. The finance committee of the Iowa Women's Coffeehouse sent the collective a letter asking for clarification, stating that it "would like the collective to let them know if the coffeehouse is considered a women's space or a lesbian space," (Letter from the Finance Committee, n.d.). The collective was evidently interested in exploring this topic because in the Iowa Women's Coffeehouse archives, an article appeared multiple times about lesbian baiting and the tensions between lesbian and straight women within feminist movements (Lesbian Baiting, n.d.). To add more confusion, the language around lesbian coffeehouses focused on "women loving women." Where then, did bisexual women fit? Hera: a Philadelphia Feminist Publication, in December 1975, ran an article entitled "My Boyfriend Dropped Me Off at the Lesbian Coffeehouse" which explained the trouble that bisexual women faced in feminist women's spaces ("My Boyfriend Dropped Me Off at the Lesbian Coffeehouse," 1975). Part of the reluctance to call lesbian spaces, "lesbian," stemmed from the contentious role of lesbians within some factions of the women's movement. Furthermore, labeling themselves as "women's" instead of "lesbian" allowed coffeehouses to be a space for questioning women, as Flavia Rando explained when discussing the Women's Coffeehouse of New York City (Rando, 2015). In 1974, the announcement for the opening of the Ann Arbor Women's Center and Coffeehouse said that it would be a "resource for women just coming out," meaning that women who attended might not have begun identifying as "lesbian" and calling it a "lesbian coffeehouse" could turn

\footnotetext{
1 "Transexual" was the more commonly used word during the 1970s and 1980s. "Transgender" has become more utilized terminology since the late 1980 s.
} 
This is the pre-peer reviewed version of the following article: Ketchum, A.D. (2020), "All Are Welcome Here"?: Navigating Race, Class, Gender, Sexual Orientation, Age, and Disability in American Feminist Coffeehouses of the 1970s and 1980s. Gender Work Organ. which has been published in final form at https://doi.org/10.1111/gwao.12595. This article may be used for noncommercial purposes in accordance with Wiley Terms and Conditions for Use of Self-Archived Versions

questioning women away (Gibson, 1974). Feminist coffeehouses struggled to define what they meant by "women" because how they defined the word could expand or restrict their community and impact.

The term "woman" within coffeehouse titles was especially controversial when the coffeehouses were deciding whether or not they were open to transgender or transsexual women. A Woman's Coffeehouse of Minneapolis purported to want to encourage diversity, however, the collective integrated transphobic and gender identity discrimination within its policies. On an index card, which was taped to the wall of the coffeehouse, the collective posted a notice to the community: "To be re-evaluated Oct/ Nov '84 Temporary Policy on Transexuals-- close vote, a decision was made that transexuals will not welcome at the coffeehouse and will be asked to leave by a collective members. NOTE: not all members are willing to enforce this policy and are not required to do so" (Policy on Transexuals, 1984). While there were issues of lesbians being excluded by feminist organizations, lesbian and women's coffeehouses would also exclude other marginalized groups, particularly transsexual individuals by using language such as, "women-born-women." Lesbian feminist activists founded the Mountain Moving Coffeehouse for Womyn and Children of Chicago (1974-2005) as a "safe-space for womynborn womyn and their young children,"(Bergquist \& McDonald, 2006). Male children over the age of two, transsexual individuals, and transgender women were not allowed to attend. The "womyn-bornwomyn" policy generated controversy beginning in the 1980s when pressure was put on the coffeehouse to allow admittance to men, as well as in the 1990s when transgender women contested it (Bergquist \& McDonald, 2006). However, the organization staunchly defended the policy and never allowed admittance to men or transgender women, preferring to close rather than broaden their membership. This kind of transphobia, framed within the language of "women-born-women," was prevalent but not unanimously accepted across feminist coffeehouses. At A Woman's Coffeehouse of Minneapolis, the collective was divided.

In addition to the confusion of whether or not the coffeehouses were for lesbians or all women, including transwomen, there were debates around whether it was separatist space and what the implications were for mothers. After the Iowa Women's Coffeehouse fundraising committee asked if the space was a women's space or a lesbian space, the committee's next question in the letter to the collective asked "IF it is considered a women's space what about boy children?" (Letter from the Finance Committee, n.d.) While the feminist coffeehouses that called themselves "women's coffeehouses" were clear about banning men, boy children posed a difficult dilemma that was not unique to the Iowa coffeehouse. When A Woman's Coffeehouse of Minneapolis sent its questionnaire to coffeehouse participants, the responses about boy children varied. As a result of the broad range of responses, the coffeehouse collective sent out a second questionnaire specifically focused on the role of children in the coffeehouse. This second questionnaire had twelve questions, which ranged from whether or not the individual filling out the survey was a mother herself, until what age should boys be allowed, if at all, and if women were interested in paying extra for childcare (Second Questionnaire, n.d.). These anonymous surveys elicited strong emotional responses. One woman remarked, I feel very strongly about being able to bring my son to the coffeehouse. I would feel very UNsupported as a lesbian mother if I couldn't bring my son. I understand putting an age limit on male children-- possibly twelve years old. It is very important that my son meet other children with lesbian mothers-- so meeting other lesbian moms would be great. I can envision potluck lunches or suppers for lesbians and their children or some planned outings-- sliding and hot chocolate, roller-skating and treats. In California, a group of lesbians rent a roller skating rink once a week for all lesbians and their children (Anonymous Questionnaire Responses, n.d.).

Many women wrote such long responses that they drew arrows directing readers to continue for the rest of their response on the back of the survey. The women who indicated that they had children wrote particularly long responses, indicating how important it was that they be able to bring their children. 
This is the pre-peer reviewed version of the following article: Ketchum, A.D. (2020), "All Are Welcome Here"?: Navigating Race, Class, Gender, Sexual Orientation, Age, and Disability in American Feminist Coffeehouses of the 1970s and 1980s. Gender Work Organ. which has been published in final form at https://doi.org/10.1111/gwao.12595. This article may be used for noncommercial purposes in accordance with Wiley Terms and Conditions for Use of Self-Archived Versions

Banning children would mean that lesbian mothers would be restricted from attending the coffeehouse, as finding a babysitter could be financially prohibitive. Another mother responded that she would drive one hundred miles to go to the coffeehouse and how much this space was needed as a place to bring kids. She continued to write: "Motherhood does not mean heterosexuality," (Anonymous Questionnaire Responses, n.d.). Furthermore, mothers argued that their children benefited from the experience of meeting other children of lesbians. Kids would face bullying at school for being the child of a lesbian mother. Meeting other children in a similar position helped them feel less isolated.

Lesbian mothers with sons felt that they faced additional hardships, both from society at large and within the lesbian community. In their responses to the questionnaires, lesbian mothers with sons expressed how other lesbians would refrain from socializing with them because they had boy children (Anonymous Questionnaire Responses, n.d.). The divide seemed particularly apparent between the mothers and non-mothers. While some women who did not have children themselves wrote on their questionnaires that they recognized the importance of women being able to bring their children in order to participate, some women were less amenable. One respondent said that she was resentful of the attention given to mothers. Another respondent went as far to say that the idea of children, "makes me shudder" and that "children should be given up for adoption," and finishing with the comment that she did not care about the age of boy children allowed at the coffeehouse because "children are children. Awake they are all disgusting" (Anonymous Questionnaire Responses, n.d.). This respondent was an outlier, as even the majority of women who expressed that they wanted the coffeehouse to be for adult women only, made clear that they were sympathetic to mothers. The antagonism between mothers and non-mothers was likely provoked due to a lack of communication about coffeehouse policies. During the open community meeting for A Woman's Coffeehouse, one participant asked why kids were running around on the dance floor, because she thought the coffeehouse provided childcare only to then be informed that the childcare was only provided during the pre-dance performance (A Woman's Coffeehouse Community, 1983). The topic of boy children and how mothers would feel welcomed as organizers and as attendees provoked strong emotions.

The question about boy children became more specific when coffeehouse members weighed in on how old the children should be if they were allowed to attend. Responding to the question about age, people typically stated that if children were allowed, boy children were only welcome until they reached puberty or became more "like men." The collective asked for recommendations for a specific age cutoff and bans were suggested on boys over the ages of five, eight, ten, eleven, and twelve (Anonymous Questionnaire Responses, n.d.). By the tenth annual New Year's Eve party, which occurred shortly after this questionnaire was circulated, the collective announced "all women, girls, and boys under ten welcome," (New Year's Eve Party Flyer, n.d.). This debate about the age of boy children was not unique to A Woman's Coffeehouse. While the Minneapolis coffeehouse's archives provide a comprehensive record of these debates in their questionnaires, taped community meeting, and in the collective's meeting minutes, it is evident that these kinds of discussions about boy children happened in feminist coffeehouse meetings across the United States. Event flyers would note "boy children allowed under twelve" and similar statements (Event Flyer, n.d.); the debate, however, would continue.

Age

Age also divided coffeehouses. It was not that certain ages were banned, with the exception of boy children over a certain age, but rather there were divisions between generations. One respondent at A Women's Coffeehouse community meeting mentioned that she sometimes felt that she could not relate to some of the younger lesbians as she had grown up having different experiences. She had become accustomed to understanding lesbian relationship dynamics as butch and femme couples pairing off (A Woman's Coffeehouse Community, 1983). However, to her, the younger lesbians were rewriting the rules. She went on to discuss one thing that could stop people from coming to the coffeehouse was "the 
This is the pre-peer reviewed version of the following article: Ketchum, A.D. (2020), "All Are Welcome Here"?: Navigating Race, Class, Gender, Sexual Orientation, Age, and Disability in American Feminist Coffeehouses of the 1970s and 1980s. Gender Work Organ. which has been published in final form at https://doi.org/10.1111/gwao.12595. This article may be used for noncommercial purposes in accordance with Wiley Terms and Conditions for Use of Self-Archived Versions

power of the coffeehouse to define the structures of who we are as lesbians" (A Woman's Coffeehouse Community, 1983). She added that some people find the definition of what it meant to be a lesbian in the coffeehouse too narrow and that it did not allow for a diversity of identities or aesthetic and lifestyle choices. This unease was rooted in different value systems regarding lesbian self-definition in 1983. Coming out before the founding of the women's community, she felt set apart from those who had come out after, particularly in terms of relationship rules. She continued, "it feels lost to her" and that she felt that "she [had] lost her history" (A Woman's Coffeehouse Community, 1983). What it meant to be a lesbian differed between generations due to the different social conditions in which they had been raised and into which they had come out. One way that A Woman's Coffeehouse attempted to rectify age differences was to create special nights dedicated to specific age groups.

A Women's Coffeehouse of Minneapolis had Old Dykes Nights, however, community members expressed that they thought it was important that socializing happened between the generations. According to a representative at the open meeting, many of the "old dykes" were absent because it was the night of their Valentine's Day dance. They had a strong community of women older than thirty-five (and their friends) that held monthly Old Dyke nights. Another participant mentioned that she knew that the coffeehouse had the Old Dyke group, but she wanted the opportunity to interact more with some of the women that were just coming out. The coffeehouse created a space for younger lesbians and women who were questioning their identities to discover themselves and find mentorship in older women of the community, at least in theory. Cliques, however, were a problem. Younger women who came to the coffeehouse would be labeled "jail bait," rather than welcomed. Participants at the meeting mentioned an issue with the music being played so loudly that it was hard to speak with women. If she wanted to hear others, she would be trapped in the front room with the smokers or crammed next to the pool table (A Woman's Coffeehouse Community, 1983). This meant it was harder for women of different generations to interact and to talk about their relationships. This desire to speak with each other was echoed when one participant mentioned that she would have come to the coffeehouse more if she could have talked to people and laughed with them and that they needed one night of the weekend devoted to that kind of thing, something where dancing was not involved. She suggested that they could have tables set up and they could talk about friendships, art, ideas, and meet people (A Woman's Coffeehouse Community, 1983). This lack of communication between different groups within the community was especially clear when it came to matters of race.

\section{Race}

Unlike feminist restaurants and cafés, which overwhelmingly white women operated, coffeehouses had greater racial diversity in their organizing collectives; yet, race remained a point of tension. On Christmas Day in 1974, the Las Hermanas Women's Cultural Center and Coffeehouse opened its doors in San Diego, California, offering a safe and welcoming space where women, particularly lesbians, could relax, enjoy homemade food, a two dollar Sunday brunch, hear live music and poetry, and socialize. The nonprofit coffeehouse was created by a group of mostly Latina women, including literature professor Dolores Valenzuela (a.k.a. "Mal Flora"), Carlota Hernandez, and Teresa Oyos (Sherman, 2010). Las Hermanas began as a seven room collective house for women who were seeking refuge from abusive spouses. At its peak from 1975 to 1978, women packed the space for "womyn's musical performances" by Meg Christian, Holly Near, Joan Armatrading, and Malvina Reynolds. The coffeehouse's popularity led to problems, especially as middle-class white women began to attend what had once been a primarily working-class, Latina coffeehouse. One of the volunteers, Diane F. Germain, remarked in a recorded interview with the LAMBDA San Diego archives,

It was mostly working-class Latina women that (formed Las Hermanas). Then, as it started to take

off and get bigger and more famous, there was kind of a set of middle-class women that came along 
This is the pre-peer reviewed version of the following article: Ketchum, A.D. (2020), "All Are Welcome Here"?: Navigating Race, Class, Gender, Sexual Orientation, Age, and Disability in American Feminist Coffeehouses of the 1970s and 1980s. Gender Work Organ. which has been published in final form at https://doi.org/10.1111/gwao.12595. This article may be used for noncommercial purposes in accordance with Wiley Terms and Conditions for Use of Self-Archived Versions

and wanted to make it better, but their idea of making it better made working-class women feel not so good (Sherman, 2010).

Working-class and middle-class white lesbians as well as straight feminists faced sexism, heterosexism, and classism, but maintained white privilege. In the case of Las Hermanas, white feminists who began to attend the coffeehouse usurped power and changed its dynamics, making the environment less friendly and inviting to the community that had formed it originally. These changes eventually led to the coffeehouse's closure. To be clear, this is not to say that all coffeehouses with predominantly white membership were oblivious to racial issues.

A Women's Coffeehouse of Minneapolis had discussions around racial diversity. During the meeting about the future of the coffeehouse, the organizers devoted twenty minutes to discussing race, stating, "we need to make sure women of color are represented...and if [there is] not a woman of color on the [organizing] collective, we need [to keep] outreach ongoing" (A Woman's Coffeehouse Community, 1983). The collective knew that the question of race would not be solved in one discussion. One meeting attendant said that a large issue was that women of color did not feel comfortable going to the coffeehouse due to the overt racism they experienced. Another participant restated what one of her friends, who was a Black woman, had once told her. She did not want to go to the coffeehouse because the white women in attendance looked at her like she was a sex object (A Woman's Coffeehouse Community, 1983). Additionally, she did not like the music and felt that the song selection catered to a specific demographic.

Not every participant was amenable to the discussion of race. One meeting attendee said, "I won't like everybody and might not like a woman of color but doesn't make me racist," (A Woman's Coffeehouse Community, 1983). Likewise, Paige, a participant, claimed that "when I go to women's festivals that there are so many committees and rules that I feel like if lesbians ran the world it would be a police state" (A Woman's Coffeehouse Community, 1983). To counter that claim, another woman stated that she felt the opposite of "what Paige said about that police state bullshit." She continued to explain that the reason they were having this discussion about race in the open community meeting was because the collective was not trying to impose a set of rules on the coffeehouse from the top but instead wanted the community to work together to create a nourishing environment. Furthermore, she was offended by "all these white women saying that they know what Black women feel." She did not want people to guess what offends Black women. Another woman countered, "So they have to tell us all?" to which the original speaker replied, "No we just shouldn't guess and use all of these analogies." Another participant had the last word when she responded, "the question should not be about whether or not racism was a problem- it was- as we are all racist" (A Woman's Coffeehouse Community, 1983). The group needed to actively work on creating diversity.

A barrier to creating diversity was that racism was so ingrained within the community itself. They had a very narrow understanding of what it meant to be a lesbian and this could lead to cliques and feelings of exclusion. One respondent mentioned that even as a white woman who did not fit all of the norms of what it meant to be a lesbian in the community, she could feel isolated, and so for women of color it would be even harder to fit those norms. Another woman chimed in that while talking about race made her nervous, she appreciated that this discussion allowed her to finally discuss her concern that the coffeehouse did not represent different cultures (A Woman's Coffeehouse Community, 1983). If the collective hoped to diversify membership, it was necessary for its members to examine the barriers that existed to participating. The current requirements required intensive time commitments and a specific lifestyle and schedule. When hiring, the collective needed to advertise beyond the communities it typically contacted. Another participant added that racial issues would not be "solved by space, money, or just committees," and that the solution was "not just being friendly to a Black woman." Instead, the 
This is the pre-peer reviewed version of the following article: Ketchum, A.D. (2020), "All Are Welcome Here"?: Navigating Race, Class, Gender, Sexual Orientation, Age, and Disability in American Feminist Coffeehouses of the 1970s and 1980s. Gender Work Organ. which has been published in final form at https://doi.org/10.1111/gwao.12595. This article may be used for noncommercial purposes in accordance with Wiley Terms and Conditions for Use of Self-Archived Versions

group needed to address the problem at "the core"(A Woman's Coffeehouse Community, 1983). A Woman's Coffeehouse was determined to try.

A Women's Coffeehouse collective of Minneapolis created the following solutions through its discussions: it established a committee to address race and diversity, dedicated funds towards hosting anti-racism workshops, and held new kinds of events. A member had suggested that women of color could host women of color only nights, similar to the over thirty-five, Old Dyke Nights. Old Dyke Nights created an opportunity for a subsection of the coffeehouse community to organize around its specific needs, however, a racially specific night made some meeting attendees uncomfortable (A Woman's Coffeehouse Community, 1983). Women of color needed to be actively involved in this process and integrated into leadership roles in order to create meaningful participation. Furthermore, another participant chimed in that the community needed to start doing workshops on racism because racism was not a problem restricted to the collective but to the entire community. The result of these discussions was that A Women's Coffeehouse created a committee on racism and race issues that first met that following April. This committee created a report that included a series of suggestions, one of which recommended that the coffeehouse develop a policy statement specifically concerning women of color. This statement advocated for all programming to take the needs and issues of women of color into consideration, that 50 percent of performers be women of color, and that 20 percent of Friday and Saturday night programming be devoted to discussing issues (non-performance presentations) specifically related to women of color. The coffeehouse would try to involve other organizations in events, broaden their publicity tactics, and educate members about subtle racism (Policy Statement, n.d.). As evidenced by later community calendars, A Women's Coffeehouse subsequently held a series of workshops about racism in the lesbian community (Women's Coffeehouse, 1981-1983). Race remained a central issue for the last four years of the coffeehouse's existence: in a 1985 flyer, the collective announced "some of our main goals are to bridge the cultural gaps between white women and women of color and break down the walls of alienation that have been built up over the years" (Anderson, 1985). While the solution was not perfect, the coffeehouse made significant efforts to address the racial divides in their organization and community.

\section{Accessibility}

Coffeehouses primarily discussed issues of accessibility related to class-consciousness. Feminist coffeehouse collectives prioritized making their spaces economically accessible by offering sliding scales for memberships, making event entrance fees by donation rather than a set price, and by allowing women to donate time and labor when money was tight. The members of A Woman's Coffeehouse also considered accessibility for women with mobility impairments. At the church where the coffeehouse occurred, the collective wanted to add a ramp. Before the ramp was installed, coffeehouse members would have to carry their friends with reduced mobility down the steps. Allegedly, the church was interested in making the entire space accessible, but it was a slow moving process (A Woman's Coffeehouse Community, 1983). As the collective only rented the space, it was limited in the kinds of changes it could make to the church itself. This didn't stop collective members from advocating for access. This kind of consciousness around accessibility was also present in the Iowa Women's Coffeehouse collective. On the June calendar for the Women's Coffeehouse of Iowa, a note at the bottom stated, "for wheelchair accessibility contact a member of the coffeehouse collective," followed by a telephone number (Women's Coffeehouse, n.d.-b). However, for the most part, when accessibility was discussed, coffeehouses typically referred to class, lesbian mothers with children, or substances.

\section{Substance Issues-Disruption over Drinking}


This is the pre-peer reviewed version of the following article: Ketchum, A.D. (2020), "All Are Welcome Here"?: Navigating Race, Class, Gender, Sexual Orientation, Age, and Disability in American Feminist Coffeehouses of the 1970s and 1980s. Gender Work Organ. which has been published in final form at https://doi.org/10.1111/gwao.12595. This article may be used for noncommercial purposes in accordance with Wiley Terms and Conditions for Use of Self-Archived Versions

While food created an environment over which women could gather, drink could be divisive. In cities where a feminist or women's business place, like a bookstore, restaurant, or bar already existed, feminist coffeehouses did not just occur as a place for women to gather. Feminist coffeehouses existed as an alternative to the bar scene and it was in this mission that food and drink became particularly important. Mountain Moving Coffeehouse of Chicago advertised itself as a drug and alcohol free space and an entertainment alternative to lesbian bars (Bergquist \& McDonald, 2006). On a flyer advertising upcoming events, the collective of the Somerville Women's Coffeehouse reminded readers that the events were also drug and alcohol free (Flyer Handwritten on Orange Paper, n.d.). In a letter sent to the community to describe the financial difficulty they were facing in 1985, the collective of A Women's Coffeehouse of Minneapolis reminded readers that

We feel strong[ly] that A Woman's Coffeehouse is vital to the Twin Cities Lesbian community. We know it is in the hearts of many, many women. We see the coffeehouse as an institution in Minneapolis, crucial for the culture and community it creates and nurtures. It is a place for women to come out, get support for sobriety (Community Letter, 1985).

The letter continued to state, "It is the only woman-only and chemically-free space in the [Twin] cities" (Community Letter, 1985). The Iowa City Women's Coffeehouse was substance free on some nights and would note these nights in their calendars (Assorted Calendars, n.d.; Women's Coffeehouse, n.d.-a). However, collective meetings would happen over beers, as noted in the meeting minutes (Assorted Meeting Minutes, n.d.). The establishment served all lesbians and women in the Iowa City area, not just the sober ones. When the coffeehouse had chemical free days, it would ban drugs, alcohol, and tobacco (Guidelines for Using the Coffeehouse Letter, n.d.). To mitigate these tensions and to strive for greater accessibility, most coffeehouses emphasized coffee, tea, and juices. Food and drink were central to community building yet coffeehouse organizers understood that the kind of refreshments provided would shape attendance.

\section{Sustainability, Attendance, and Closure}

Most of the suggestions are about how we can spend more money but how I feel is how most of the community is not supporting this place (A Woman's Coffeehouse Community, 1983).

Changing cultural attitudes around feminism and lesbian identities made keeping a sustainable clientele difficult. Financial worries and concerns regarding diversity were intertwined with dwindling attendance. When A Woman's Coffeehouse of Minneapolis circulated a letter asking for donations, the collective noted, "the coffeehouse has steadily lost money all year due to rising costs and declining attendance" (Community Letter, 1985). Dwindling attendance pushed the coffeehouse to the edge of bankruptcy and the collective emphasized, "IT IS URGENT THAT YOU SUPPORT THE COFFEEHOUSE THROUGH THIS CRISIS IN SPITE OF WHATEVER CHANGES YOU WISH FOR, SO THAT IT WILL CONTINUE TO BE HERE FOR ALL OF US"(Community Letter, 1985, emphasis in the document). A Woman's Coffeehouse was not the only one to struggle. Las Hermanas of San Diego, California closed in 1980 over conflict, lack of interest, and an increase in rent. A February 1980 article explained Las Hermanas' closure, stating that over the past five years conditions changed, "many new groups have formed, providing women with many choices for involving themselves politically, socially and culturally. Las Hermanas slowly and somewhat painfully declined in popularity and the nucleus of women nurturing it over the years have become exhausted" (Sherman, 2010). Divisions over class, race, gender, and sexual orientation led to decreased attendance, subsequent 
This is the pre-peer reviewed version of the following article: Ketchum, A.D. (2020), "All Are Welcome Here"?: Navigating Race, Class, Gender, Sexual Orientation, Age, and Disability in American Feminist Coffeehouses of the 1970s and 1980s. Gender Work Organ. which has been published in final form at https://doi.org/10.1111/gwao.12595. This article may be used for noncommercial purposes in accordance with Wiley Terms and Conditions for Use of Self-Archived Versions

financial issues, and the ultimate demise of most coffeehouses. Most feminist coffeehouses founded in the 1970s and 1980s in the United States closed by the 1990s.

\section{Conclusion}

The phenomenon of feminist coffeehouses in the 1970s and 1980s in the United States expanded the possibilities of who could organize feminist space centered on food, drink, and socializing. Without high fixed costs, coffeehouses enabled women with less access to capital to create women centered spaces that offered refreshments. While food bolstered community building, debates surrounding representation and inclusion/exclusion proved to be ongoing sources of conflict. Tensions were particularly high regarding issues of race, gender, sexual orientation, and age. Coffeehouse members disagreed about the inclusion of mothers and their children, the use of substances like alcohol, and how to make the space welcoming to new attendees. Trying to adapt to community needs was a difficult but important task for creating the kinds of places that organizers and attendees wanted, whether it was dancing, poetry, music, or just socializing.

Even when coffeehouse collectives endeavored to make a space welcoming to all groups, such lofty goals were often out of reach. Although groups purported that their space was welcoming to all women, when women of color were not centrally involved in organizing and creating a vision for the coffeehouses, mostly white women utilized the spaces. When only women without children created rules, mothers with sons faced barriers. It was not about just adding specific women to the location to create diversity but that women of diverse backgrounds needed to be involved in forming the entire structure.

In presenting feminist coffeehouses in the United States as a case study of feminist organizations in a particular historical context, I have attempted to show that despite the difficulty of creating a community based on shared values that is also open to a diverse constituency, such efforts are necessary. Feminism is a process of working towards a more socially just world. The history of feminist coffeehouses sheds light on the complexity of power relations within feminist organizations and underscores the need for ongoing reflection and adaptation within feminist enterprises. The lessons garnered from the rise and fall of coffeehouses provide guidance in resolving political friction around intragroup dynamics and division amongst feminists today. If these findings are not taken into account, present feminist organizations risk reproducing hierarchies of power across race, class, gender, and sexuality.

\section{References}

A Woman's Coffeehouse Community. (1983). Open Community Meeting. University of Minneapolis Libraries and Archives - Jean Nickolaus Tretter Collection in GLBT Studies (A Woman's Coffeehouse Collective Records 1976-1985, Box 1, A Woman's Coffeehouse Meeting Cassette Tapes, 1983).

A Woman's Coffeehouse Community. (n.d.). Collective Member Application. Retrieved from University of Minneapolis Libraries and Archives - Jean Nickolaus Tretter Collection in GLBT Studies. (A Woman's Coffeehouse Collective Records 1976-1985, Box 1)

Anderson, S. (1985, December 18). Coffeehouse Makes Changes. Equal Times, p. 9. 
This is the pre-peer reviewed version of the following article: Ketchum, A.D. (2020), "All Are Welcome Here"?: Navigating Race, Class, Gender, Sexual Orientation, Age, and Disability in American Feminist Coffeehouses of the 1970s and 1980s. Gender Work Organ. which has been published in final form at https://doi.org/10.1111/gwao.12595. This article may be used for noncommercial purposes in accordance with Wiley Terms and Conditions for Use of Self-Archived Versions

Anonymous Questionnaire Responses. (n.d.). Retrieved from University of Minneapolis Libraries and Archives - Jean Nickolaus Tretter Collection in GLBT Studies. (A Woman's Coffeehouse Collective Records 1976-1985, Box 1, Questionnaires)

Assorted Calendars. (n.d.). Retrieved from University of Iowa Women's Archives Collection. (Jill Jack Papers (IWA0519), Activism Series 2, Box 1, Women's Coffeehouse: Calendar Pages, 19811983)

Assorted Meeting Minutes. (n.d.). Retrieved from University of Iowa Women's Archives Collection. (Jill Jack Papers (IWA0519), Activism Series 2, Box 1, The Women's Coffeehouse Histories, Policies, and Finances, 1981-1982, undated)

Back Cover. (1975, May). Hera: A Philadelphia Feminist Publication, 1(2), Back Cover.

Baines, S., \& Wheelock, J. (2000). Work and employment in small businesses: perpetuating and challenging gender traditions. Gender, Work \& Organization, 7(1), 45-56.

Bell, K., Salmon, A., Bowers, M., Bell, J., \& McCullough, L. (2010). Smoking Stigma and Tobacco "Denormalization:" Further Reflections on the Use of Stigma as a Public Health Tool A commentary on Social Science \& Medicine's Stigma, Prejudice, Discrimination and Health Special Issue. Social Science \& Medicine, 70(6), 795-799.

Bergquist, K., \& McDonald, R. (2006). A Field Guide to Gay and Lesbian Chicago. Chicago: Lake Claremont Press.

Boyd, N. A. (2003). Wide-open town: A history of queer San Francisco to 1965. Univ of California Press.

Cvetkovich, A., \& Wahng, S. (2001). Don't stop the music: Roundtable discussion with workers from the Michigan Womyn's Music Festival. GLQ: A Journal of Lesbian and Gay Studies, 7(1), 131151.

Community Letter. (1985). University of Minneapolis Libraries and Archives - Jean Nickolaus Tretter Collection in GLBT Studies (A Woman's Coffeehouse Collective Records 1976-1985, Box 1, Letters).

Eder, D., Staggenborg, S., \& Sudderth, L. (1995). The National Women's Music Festival: Collective identity and diversity in a lesbian-feminist community. Journal of Contemporary Ethnography, 23(4), 485-515.

Event Flyer. (n.d.). Retrieved from GLBT Historical Society of San Francisco Archives. (San Francisco LGBT Business Ephemera Collection (\#BUS EPH))

Flyer Handwritten on Orange Paper. (n.d.). Retrieved from Northeastern University Archives. (Somerville Women's Educational Center 1975-1983 (M26), Box 4 "Projects: Coffeehouse: Fliers and Notes," Folder 65: Philosophy and Notes)

Full Moon Open Community Letter. (n.d.). GLBT Historical Society of San Francisco Archives (Full Moon Coffee House Runion Records (\#1992-13), 1974-1988).

Gibson, J. (1974). Ann Arbor Women's Center and Coffeehouse. Ain't I A Woman, 3(7).

Guidelines for Using the Coffeehouse Letter. (n.d.). Retrieved from University of Iowa Women's Archives Collection. (Jill Jack Papers (IWA0519), Activism Series 2, Box 1, The Women's Coffeehouse Histories, Policies, and Finances, 1981-1982, undated)

Heaney, E. (2016). Women-Identified Women: Trans Women in 1970s Lesbian Feminist Organizing. Transgender Studies Quarterly, 3(1-2), 137-145.

Hogan, K. (2016). The feminist bookstore movement: Lesbian antiracism and feminist accountability. Duke University Press.

June Letter [Letter]. (1982, June). University of Iowa Women's Archives Collection (Jo Rabenold Papers (IWA0191), Series 5: Organizations, Box 4, Women's Coffeehouse: Organizational History and Pledge Drives, 1981-1982). 
This is the pre-peer reviewed version of the following article: Ketchum, A.D. (2020), "All Are Welcome Here"?: Navigating Race, Class, Gender, Sexual Orientation, Age, and Disability in American Feminist Coffeehouses of the 1970s and 1980s. Gender Work Organ. which has been published in final form at https://doi.org/10.1111/gwao.12595. This article may be used for noncommercial purposes in accordance with Wiley Terms and Conditions for Use of Self-Archived Versions

Lesbian Baiting. (n.d.). Retrieved from University of Iowa Women's Archives Collection. (Jo Rabenold Papers (IWA0191), Series 5: Organizations, Box 4)

Letter from the Finance Committee. (n.d.). University of Iowa Women's Archives Collection (Jo Rabenold Papers (IWA0191), Series 5: Organizations, Box 4, Women's Coffeehouse: Organizational History and Pledge Drives, 1981-1982).

Letter from the Pledge Committee. (n.d.). University of Iowa Women's Archives Collection (Jo Rabenold Papers (IWA0191), Series 5: Organizations, Box 4, Women's Coffeehouse: Organizational History and Pledge Drives, 1981-1982).

Liddle, K. (2005). More than a bookstore: The continuing relevance of feminist bookstores for the lesbian community. Journal of Lesbian Studies, 9(1-2), 145-159.

Meeting Minutes. (1979). Retrieved from Northeastern University Archives. (Somerville Women's Educational Center 1975-1983 (M26), Box 4 "Projects: Coffeehouse: Fliers and Notes," Folder 65: Philosophy and Notes)

Meeting Minutes. (1980, July 10). Retrieved from University of Iowa Women's Archives Collection. (Jill Jack Papers (IWA0519), Activism Series 2, Box 1, The Women's Coffeehouse Histories, Policies, and Finances, 1981-1982, undated)

Murray, H. (2007). Free for All Lesbians: Lesbian Cultural Production and Consumption in the United States during the 1970s. Journal of the History of Sexuality, 16(2), 251-275.

My Boyfriend Dropped Me Off at the Lesbian Coffeehouse. (1975, December). Hera: A Philadelphia Feminist Publication, 1(5), 17.

New Year's Eve Party Flyer. (n.d.). Retrieved from University of Minneapolis Libraries and Archives Jean Nickolaus Tretter Collection in GLBT Studies. (A Woman's Coffeehouse Collective Records 1976-1985, Box 1, Miscellaneous and AWC Poster, 1984-1985)

Oldenburg, R. (1999). The great good place: Cafes, coffee shops, bookstores, bars, hair salons, and other hangouts at the heart of a community. Da Capo Press.

Policy on Transexuals. (1984). Retrieved from University of Minneapolis Libraries and Archives - Jean Nickolaus Tretter Collection in GLBT Studies. (A Woman's Coffeehouse Collective Records 1976-1985, Box 1, Policy on Transexuals)

Policy Statement. (n.d.). Retrieved from University of Minneapolis Libraries and Archives - Jean Nickolaus Tretter Collection in GLBT Studies. (A Woman's Coffeehouse Collective Records 1976-1985, Box 1, Committees (CH))

Rando, F. (2015, March 7). New York Feminist Food (A. Ketchum, Interviewer). Reno, M. (1974). Women's Coffeehouse. Herself: Women's Community Journal, 3(4). Rousseau, C. (2015). Wages Due Lesbians: Visibility and Feminist Organizing in 1970s Canada. Gender, Work \& Organization, 22(4), 364-374.

Rudy, K. (2001). Radical feminism, lesbian separatism, and queer theory. Feminist Studies, 27(1), 191222.

Second Questionnaire. (n.d.). Retrieved from University of Minneapolis Libraries and Archives - Jean Nickolaus Tretter Collection in GLBT Studies. (A Woman's Coffeehouse Collective Records 1976-1985, Box 1, Questionnaires)

Sherman, P. (2010, December 9). A Moment in Time: Las Hermanas (The Sisters). Gay San Diego. Retrieved from https:/gay-sd.com/moments-in-time-las-hermanas-the-sisters/

Stryker, S. (2008). Transgender history: The roots of today's revolution. Seal Press.

Thank You [Letter]. (n.d..). University of Iowa Women's Archives Collection (Jo Rabenold Papers (IWA0191), Series 5: Organizations, Box 4, Women's Coffeehouse: Signs, Flyers and Calendars, 1975-1982).

Vitry, C. (2020). Queering Space and Organizing with Sara Ahmed's Queer Phenomenology. Gender, Work \& Organization, Accepted Author Manuscript. doi:10.1111/gwao. 12560 
This is the pre-peer reviewed version of the following article: Ketchum, A.D. (2020), "All Are Welcome Here"?: Navigating Race, Class, Gender, Sexual Orientation, Age, and Disability in American Feminist Coffeehouses of the 1970s and 1980s. Gender Work Organ. which has been published in final form at https://doi.org/10.1111/gwao.12595. This article may be used for noncommercial purposes in accordance with Wiley Terms and Conditions for Use of Self-Archived Versions

Women's Coffeehouse. (n.d.-a). Calendars. Retrieved from University of Iowa Women's Archives Collection. (Jo Rabenold Papers (IWA0191), Series 5: Organizations, Box 4, Women's Coffeehouse: Signs, Flyers and Calendars, 1975-1982)

Women's Coffeehouse. (n.d.). Coffeehouse Calendar. Retrieved from University of Iowa Women's Archives Collection. (Jill Jack Papers (IWA0519), Activism Series 2, Box 1, Women's Coffeehouse: Calendar Pages, 1981-1983)

Women's Coffeehouse. (1981). Community Letter. University of Iowa Women's Archives Collection (Jill Jack Papers (IWA0519), Activism Series 2, Box 1, The Women's Coffeehouse Histories, Policies, and Finances, 1981-1982, undated).

Women's Coffeehouse. (n.d.-b). June Coffeehouse Calendar. Retrieved from University of Iowa Women's Archives Collection. (Jill Jack Papers (IWA0519), Activism Series 2, Box 1, Women's Coffeehouse: Calendar Pages, 1981-1983) 